\section{Reducing Preharvest Bolting in Open- field-grown Cilantro (Coriandrum sativum L. cv. Santo) through Use of Growth Regulators}

\author{
Bo Meyering, Adam Hoeffner, and Ute Albrecht \\ Southwest Florida Research and Education Center, University of Florida/ \\ IFAS, 2685 State Road 29 North, Immokalee, FL 34142
}

Additional index words. coriander, gibberellin, gibberellin biosynthesis inhibitors, plant growth regulators

\begin{abstract}
Cilantro (Coriandrum sativum L.), also called coriander, is an herbaceous, annual plant that is cultivated worldwide for its leaves and seeds. Cilantro has a strong propensity to bolt quickly in hot weather and under long-day (LD) conditions, which affects the flavor and renders the crop unmarketable. High incidence of preharvest bolting in open-field production can cause significant economic loss. The phytohormone gibberellic acid (GA) regulates stem elongation and floral initiation in many LD rosette plants. In pilot experiments, we found that GA induced bolting in greenhouse-grown cilantro and that plant growth regulators (PGRs) with anti-GA activity can delay this process. We then explored the effects of different GA inhibitors on reducing the incidence of bolting in cilantro grown in a commercial open-field environment. Four field trials were conducted on a commercial farm near Clewiston in Florida between Fall 2016 and Spring 2018. Different growth regulators were applied at different times, ranging from 5 to 8 weeks after seeding (WAS), and plants were harvested 2 to 3 weeks thereafter. Applications of GA inhibitors significantly reduced the incidence of bolting in three of the four trials, but the extent depended on the type of inhibitor used. The results from one trial were inconclusive due to changes in weather that prevented bolting in the entire field. Overall, plots treated with prohexadione calcium and paclobutrazol were most effective and reduced bolting by up to $78 \%$. Applying the PGRs at 5 and 6 WAS was more effective than at 7 or 8 WAS.
\end{abstract}

Coriander (Coriandrum sativum L.) or cilantro, as it is commonly called in the United States, is an herbaceous, annual plant with a basal rosette growth habit that belongs to the family Apiaceae and is widely cultivated throughout the world (Morales-Payan, 2011). Both the seeds and vegetative parts of the plant contain high levels of essential oils and organic compounds with broad medicinal properties (Laribi et al., 2015). Cilantro is grown mostly for its dried fruits, although its

Received for publication 2 Oct. 2019. Accepted for publication 31 Oct. 2019

Published online 16 December 2019

We thank Thang Kim, Gustavo Piccin, Indu Tripathi, and Gabriel Pugina for their support in the field and with laboratory measurements. We also thank Chuck Obern (C\&B Farms) for his support and helpful discussions and for allowing us to conduct the field trials at his farm.

This paper is associated with a presentation titled "Using Plant Growth Regulators to Reduce Bolting in Cilantro (Coriandrum sativum)" given during the 2019 Annual Meeting of the Florida State Horticultural Society, which was held 9-11 June in Orlando, FL.

U.A. is the corresponding author. E-mail: ualbrecht@ ufl.edu.

This is an open access article distributed under the CC BY-NC-ND license (https://creativecommons. org/licenses/by-nc-nd/4.0/). highly aromatic leaves, which are used to flavor a variety of dishes from salsas to curries, are the main part of the plant conbeen conclusively determined, but most accessions can be placed into one of two broad categories: 1) those that originated in the Caucasus and Central Asia and are characterized by a prolonged vegetative growth state with many basal rosette leaves and 2) those that originated in the Near East and the Indian subcontinent where cultural selection favored quick flowering and large fruits over leaf production (Diederichsen, 1996).

Commercially grown cilantro is commonly cultivated in open field systems and suffers from relatively few production problems, although bacterial leaf spot, Phytophthora root rot, and Fusarium wilt can sometimes cause economic damage (Dugan et al., 2017; Pernezny et al., 1997). Several studies have explored various treatments and storage methods to increase its postharvest shelf life (Hassan and Mahfouz, 2012; Luo et al., 2004), and the effects of fertilization and water use have also been investigated extensively (Angeli et al., 2016). However, one persistent physiological trait of cilantro that has received proportionately little attention is its propensity to "bolt" or initiate rapid stem elongation from the rosette and flower under certain environmental condisumed in the United States. Its origin has not tions, causing the leaves to assume an unpleasant flavor (Bashtanova and Flowers, 2011). This averse flavor, which is most likely due to changes in the essential oil composition in the leaves (Potter, 1996), renders the crop unmarketable. During the winter in south Florida, it is possible to harvest a crop twice before bolting commences, but this becomes increasingly difficult as temperatures start to rise (Chuck Obern, personal communication, 2016). The relationship of cilantro bolting to increases in temperature and LD environmental conditions has been suggested in several extension publications; however, these provide little more than general observations on yield and early flowering (Blade et al., 2016; Smith et al., 2011).

Putievsky (1983) showed that LD conditions accelerate cilantro flowering but reduce overall yield, and Nawata et al. (1995), in their survey of cilantro landraces in southeast Asia, gathered evidence suggesting that cilantro is a facultative LD plant. Tomitaka et al. (2001) later provided support for these results by examining the stages of floral development in relation to changes in daylength through a series of controlled greenhouse experiments. Their results showed a strong, negative linear relationship between photoperiod and the elapsed time until flowering, even though flowering eventually occurred in all photoperiods tested. In their study, flower bud pre-differentiation occurred at an average of $49 \mathrm{~d}$ after seeding under daylength neutral conditions. This is in agreement with values published elsewhere (Diederichsen and Hammer, 2003).

Plant growth, development, and organ ontogenesis are complex processes, which are highly regulated by endogenous plant hormones and genetic and epigenetic control of regulatory pathways (Bishopp et al., 2006; Johnson and Lenhard, 2011; Pikaard and Scheid, 2014). Floral development and regulation in several other Apiaceous species are well understood and were shown to be regulated mainly through photoperiod and vernalization. Dill (Anethum graveolens), an LD plant, can be induced to flower once exposed to a single 11-hour daylength cycle, and early flowering is accompanied by lower vegetative yields (Hälvä et al., 1993; Hamner and Naylor, 1939). Similarly, fennel (Foeniculum vulgare) will bolt after being exposed to several photoperiod cycles for a minimum of $13.5 \mathrm{~h}$ (Peterson et al., 1993). Several other studies reported that celery (Apium graveolens) is a day-neutral species that is induced to flower by vernalization (Jenni et al., 2005), although LD conditions after vernalization treatments greatly reduced the time to bolting (Ramin and Atherton, 1994).

Floral induction in Arabidopsis thaliana, also a facultative LD plant with basal rosette growth, has been studied extensively and is highly regulated by several integrated pathways that monitor both environmental and plant internal conditions (Simpson and Dean, 2002). Bioactive gibberellins (GA) are a class 
of endogenous phytohormones that positively direct seed germination, stem elongation, and floral initiation and significantly interact with the auxin-cytokinin pathways for root and shoot meristem development (Vanstraelen and Benková, 2012). Arabidopsis mutants deficient in GA synthesis genes show extreme dwarfing phenotypes with tight rosette patterns and are nonresponsive to $\mathrm{LD}$ inductive conditions, supporting the role that GA plays in integrating these two pathways (Reeves and Coupland, 2001).

Several studies have investigated the effects of exogenously applied GA in cilantro to increase yield. Das et al. (2018) found that a 20 ppm GA application at 25 and $30 \mathrm{~d}$ after seeding increased leaf yield by $47 \%$, but they did not comment on the incidence of preharvest flowering. Morales-Payan and Stall (2004) also observed a significant yield increase with GA applications. GA applied at rates of 10 and $20 \mathrm{~g} \cdot \mathrm{ha}^{-1}$ to plots of cilantro at 7 WAS had no effect on overall yield but significantly increased preharvest bolting and plant height (Kahn and Maness, 2010). When applied to plots at rates of 50 to $75 \mathrm{ppm}$, GA increased the number of flowering umbels, plant height, seed yield, and size and decreased the days to flowering and seed maturity (Yugandhar et al., 2016). Although early flowering and increased seed yield are beneficial traits for cultivation of coriander fruit, this is not the case when leaf production is the objective. Applying auxin or cytokinin to the foliage to prevent early bolting has been proposed, but no evidence was provided for its efficacy (Morales-Payan, 2011), and to date, no studies have specifically examined any methods to reduce the incidence of preharvest bolting in the field.

PGRs are synthetically produced compounds which alter growth and development and can attenuate the effects of environmental conditions and of endogenous phytohormones such as GA (Rademacher, 2015). Some compounds such as the diethanolamine salt of mefluidide (MFL) are cell division inhibitors and are used strictly to inhibit seedhead formation in turfgrass (Haguewood et al., 2013). Other PGRs, such as chlormequat chloride (CQC), paclobutrazol (PBZ), flurprimidol, and prohexadione calcium (PCa), directly inhibit GA biosynthesis (Rademacher, 2016). Currently, PCa has widespread use in controlling fire blight in apples (McGrath et al., 2009), reducing vegetative growth in peanuts (Beam et al., 2002), and decreasing shoot growth in apples and cherries (Cline, 2017). Although PBZ is mainly used in the ornamental plant industry, it has some efficacy in reducing shoot growth in tropical and subtropical tree crops (Rademacher, 2016).

It is possible to control certain environmental conditions within a greenhouse setting; however, it is currently not practical to do so in open production systems. Given our assumptions that cilantro is induced under LD conditions and that GA at least partially controls stem elongation and floral initiation in cilantro, we hypothesized that PGRs that inhibit GA biosynthesis would decrease the incidence of early bolting in the field. The objective of our study was therefore to determine the efficacy of several commercially available GA inhibitors to prolong the vegetative stages of cilantro in the field and to identify the appropriate time at which to apply these products.

\section{Materials and Methods}

\section{Greenhouse experiments}

Plant material. Two pilot experiments were conducted in an enclosed greenhouse to screen prospective antigibberellin compounds and identify appropriate concentrations for spray application. One-gallon nursery containers (Pro-Cal, South Gate, CA) were surface sterilized with a $1 \% \mathrm{NaClO}$ solution and air-dried. Cilantro seeds (cv. Santo) were sown into sterilized pots filled with Fafard \#2 potting medium (Sun Gro Horticulture, Agawam, MA). Both the seeds and potting medium were pretreated with Oxidate 2.0 (BioSafe Systems LLC, East Hartford, CT) according to the manufacturer's directions. Seeds were germinated and then thinned to six seedlings per pot. Once the first true leaf was fully expanded, pots were fertilized three times per week with $150 \mathrm{~mL}$ of a watersoluble fertilizer at $100 \mathrm{ppm} \mathrm{N}$ (Peter's Professional, $20 \mathrm{~N}-10 \mathrm{P}_{2} \mathrm{O}_{5}-20 \mathrm{~K}_{2} \mathrm{O}$, Israel Chemicals Ltd., Tel Aviv, Israel). The fertilizer dosage was increased to $300 \mathrm{~mL}$ starting at $6 \mathrm{WAS}$ as the plants began to mature.

Experimental design. Plants were arranged on the greenhouse benches in a completely randomized design (CRD) with 6 replicates per treatment. Each replicate consisted of one pot containing 6 plants.

Treatments. PGRs applied to plants in Expt. 1 were PBZ (paclobutrazol, Bonzi, $0.4 \%$, Syngenta, Greensboro, NC) at $3 \mathrm{mg} \cdot \mathrm{L}^{-1}$ a.i., CQC (chlormequat chloride, Cycocel $11.8 \%$, OHP, Bluffton, SC) at $2000 \mathrm{mg} \cdot \mathrm{L}^{-1}$ a.i., and GA (gibberellic acid, N-large $4 \% \mathrm{GA}_{3}$, Stoller) at $25 \mathrm{mg} \cdot \mathrm{L}^{-1}$ a.i. as a positive control. PGRs applied to plants from Expt. 2 included PBZ and GA at the same rates used in Expt. 1. In addition, $\mathrm{PCa} 1$ (prohexadione calcium, Apogee, $27.5 \%(\mathrm{w} / \mathrm{w})$, BASF Corporation, Florham, NJ) at $119 \mathrm{mg} \cdot \mathrm{L}^{-1}$ a.i. and MFL (mefluidide, Embark 3.2\%, PBI/Gordon Corporation, Kansas City, MO) at $45 \mathrm{mg} \cdot \mathrm{L}^{-1}$ a.i. were used. CQC was used in Expt. 1 as a proof of concept but later omitted because of its restricted use in an open-field environment. PBZ was applied as a 200-mL drench; all other materials were applied foliar with a handheld sprayer and included Tween 20 (SigmaAldrich, St. Louis, MO) at $0.1 \%(\mathrm{v} / \mathrm{v})$ as a surfactant. The spray volume per pot was $\approx 50$ $\mathrm{mL}$, which was enough to cover the leaves until runoff. An untreated control (UTC) using water and surfactant only was included in each experiment. In Expt. 1, plants were sprayed at 8 WAS and evaluated 10 WAS. In Expt. 2 plants were sprayed at 5 WAS and evaluated at 8 WAS. The average daylength during the experiments was 11.25 and $11.5 \mathrm{~h}$ for Expts. 1 and 2, respectively. Treatments and supporting information are summarized in Table 1.

\section{Field trials}

Field location and management. Four field trials were conducted on a commercial vegetable farm in Clewiston, FL (lat. $26^{\circ} 27^{\prime} 18^{\prime \prime} \mathrm{N}$, long. $\left.81^{\circ} 1^{\prime} 52^{\prime \prime} \mathrm{W}\right)$. Trial 1 was conducted in Winter 2016, trials 2 and 3 in Spring 2017, and trial 4 in Spring 2018. The prominent soil type at the farm site is siliceous Basinger fine sand, which is typically poorly drained but rapidly permeable (Soil Survey Staff, Natural Resources Conservation Service, U.S. Department of Agriculture, Official Soil Series Descriptions, 2014). Cilantro seeds (cv. Santo) were sown in 1.27 -m-wide $\times 30.0-\mathrm{m}$-long raised beds with five rows per bed. Fields were broadcast fertilized with a granular fertilizer containing $\mathrm{N}, \mathrm{P}, \mathrm{K}\left(7 \mathrm{~N}-9 \mathrm{P}_{2} \mathrm{O}_{5}-17 \mathrm{~K}_{2} \mathrm{O}\right)$ at a rate of 672.1 $\mathrm{kg} \cdot \mathrm{ha}^{-1}$ and then supplemented with three side dress applications of liquid fertilizer containing $10 \mathrm{~N}-0 \mathrm{P}-8 \mathrm{~K}_{2} \mathrm{O}$ at a rate of 375 $\mathrm{L} \cdot \mathrm{ha}^{-1}$ for a total of $134.5 \mathrm{~kg} \cdot \mathrm{ha}^{-1} \mathrm{~N}$. Liquid fertilizer applications were performed at 2, 4, and 6 WAS. Irrigation was by seepage, and pest and disease management was performed according to the grower's standard practice. Average daylength ranged from $10.5 \mathrm{~h}$ during trial 1 to $11.9 \mathrm{~h}$ during trial 4 , and the average temperatures ranged from $19.6^{\circ} \mathrm{C}$ during trial 3 to $21.4{ }^{\circ} \mathrm{C}$ during trial 4 (Table 1 ).

Experimental design. The experimental design was a randomized complete block design (RCBD) using four replicates (trials 1-3) or six replicates (trial 4) per treatment. Each treatment plot was $1.27 \mathrm{~m}$ (the width of one bed $) \times 3.66 \mathrm{~m}\left(4.65 \mathrm{~m}^{2}\right)$ in size with a 0.2 $\mathrm{m}$ buffer area between plots to reduce the chance of spray carryover from adjacent plots. The treatments were applied to the entire plot, and sampling was conducted on a smaller subplot, which excluded $0.6 \mathrm{~m}$ on either end of the plot as well as the outer two rows of cilantro within a bed to minimize any edge effect. Plants from field trials 1, 2, and 3 were harvested and evaluated at $8 \mathrm{WAS}$, and plants from trial 4 were harvested at 9 WAS, coinciding with the grower's harvest of the remainder of the field.

Treatments. Treatments were applied using a motorized backpack sprayer equipped with a flat fan nozzle wand (Solo 417, Solo Inc., Newport News, VA) and were sprayed at 40 psi. All materials were applied together with a liquid soap (Dawn, Proctor \& Gamble, Cincinnati, $\mathrm{OH}$ ) as adjuvant favored by the grower at $0.1 \%(\mathrm{v} / \mathrm{v})$. The UTC plants were sprayed with the adjuvant only. The total spray volume for each plot was $3.785 \mathrm{~L}$ for field trials 1 through 3 and $325 \mathrm{~mL}$ for field trial 4. Treatments for field trial 1 were applied in Dec. 2016 at 5 WAS. The time of application was 10:00 HR. The PGRs used were PBZ applied as a sprench ("sprayed drench" directed at the soil surface near the stem) at $3 \mathrm{mg} \cdot \mathrm{L}^{-1}$ a.i. and PCa1 applied foliar at $42.5 \mathrm{mg} \cdot \mathrm{L}^{-1}$ a.i. Field trials 2 and 3 were sown 1 week apart in neighboring fields. Treatments were applied at 10:00 HR on the same day in Feb. 2017 at 6 WAS (trial 2) and at 5 WAS (trial 3). The plant growth regulators used were PBZ applied as a sprench at 
Table 1. Treatments, treatment rates, planting dates, application times, and other supporting information of cilantro (cv. Santo) greenhouse experiments and field trials conducted in this study.

\begin{tabular}{|c|c|c|c|c|c|c|}
\hline & \multicolumn{2}{|c|}{ Greenhouse experiments } & \multicolumn{4}{|c|}{ Field trials } \\
\hline & 1 & 2 & 1 & 2 & 3 & 4 \\
\hline \multicolumn{7}{|c|}{ Treatments and treatment rates } \\
\hline GA & $25 \mathrm{mg} \cdot \mathrm{L}^{-1}$ & $25 \mathrm{mg} \cdot \mathrm{L}^{-1}$ & - & - & - & - \\
\hline PBZ & $3 \mathrm{mg} \cdot \mathrm{L}^{-1}$ & $3 \mathrm{mg} \cdot \mathrm{L}^{-1}$ & $3 \mathrm{mg} \cdot \mathrm{L}^{-1}$ & $6 \mathrm{mg} \cdot \mathrm{L}^{-1}$ & $6 \mathrm{mg} \cdot \mathrm{L}^{-1}$ & - \\
\hline PCa1 & - & $119 \mathrm{mg} \cdot \mathrm{L}^{-1}$ & $42.5 \mathrm{mg} \cdot \mathrm{L}^{-1}$ & $42.5 \mathrm{mg} \cdot \mathrm{L}^{-1}$ & $42.5 \mathrm{mg} \cdot \mathrm{L}^{-1}$ & $42.5 \mathrm{mg} \cdot \mathrm{L}^{-1}$ \\
\hline $\mathrm{PCa} 2$ & - & - & - & - & - & $42.5 \mathrm{mg} \cdot \mathrm{L}^{-1}$ \\
\hline CQC & $2000 \mathrm{mg} \cdot \mathrm{L}^{-1}$ & - & - & - & - & - \\
\hline MFL & - & $45 \mathrm{mg} \cdot \mathrm{L}^{-1}$ & - & $45 \mathrm{mg} \cdot \mathrm{L}^{-1}$ & $45 \mathrm{mg} \cdot \mathrm{L}^{-1}$ & - \\
\hline \multicolumn{7}{|l|}{ Supporting information } \\
\hline Planting date & 21 Sept. 2016 & 23 Jan. 2017 & 11 Sept. 2016 & 12 Jan. 2017 & 21 Jan. 2017 & 2 Apr. 2018 \\
\hline Application time & 8 WAS & 5 WAS & 5 WAS & $6 \mathrm{WAS}$ & 5 WAS & $6,7,8 \mathrm{WAS}$ \\
\hline Evaluation time & $10 \mathrm{WAS}$ & 8 WAS & 8 WAS & 8 WAS & 8 WAS & 9 WAS \\
\hline Avg daylength (h) & 11.25 & 11.5 & 10.5 & 11.25 & 11.5 & 11.9 \\
\hline Avg high temp $\left({ }^{\circ} \mathrm{C}\right)$ & 29.9 & 27.5 & 28.0 & 27.9 & 27.6 & 29.2 \\
\hline Avg low temp $\left({ }^{\circ} \mathrm{C}\right)$ & 18.8 & 13.1 & 15.5 & 14.0 & 13.1 & 15.0 \\
\hline Avg temp $\left({ }^{\circ} \mathrm{C}\right)$ & 23.3 & 19.5 & 20.8 & 20.0 & 19.6 & 21.4 \\
\hline
\end{tabular}

Treatment rates listed are $\mathrm{mg}$ of a.i. per liter. $\mathrm{GA}=$ gibberellic acid; $\mathrm{PBZ}=$ paclobutrazol; $\mathrm{PCa} 1$ and $\mathrm{PCa} 2=$ prohexadione calcium; $\mathrm{CQC}=$ chlormequat chloride; $\mathrm{MFL}=$ mefluidide; WAS $=$ weeks after seeding.

$6 \mathrm{mg} \cdot \mathrm{L}^{-1}$ a.i., $\mathrm{PCa} 1$ applied as a foliar spray at $42.5 \mathrm{mg} \cdot \mathrm{L}^{-1}$ a.i., and MFL applied as a foliar spray at $45 \mathrm{mg} \cdot \mathrm{L}^{-1}$ a.i. Plants from field trials 1 through 3 were evaluated 8 WAS.

In field trial 4 , we explored the interaction of treatment and application time. In addition to $\mathrm{PCa} 1$, a second prohexadione calcium material, PCa2 [Kudos, 27.5\% (w/w), Fine Americas Inc., Walnut Creek, CA] was used. Both materials were applied as foliar sprays at $42.5 \mathrm{mg} \cdot \mathrm{L}^{-1}$ a.i. with spray grade AMS (21-0-0) at $476 \mathrm{mg} \cdot \mathrm{L}^{-1}$ to facilitate uptake into the leaves and a nonionic surfactant (Activator 90, Loveland Products Inc., Loveland, $\mathrm{CO}$ ) at $1.25 \mathrm{~mL} \cdot \mathrm{L}^{-1}$ according to the manufacturer's recommendations. The UTC consisted of AMS and nonionic surfactant only. The total spray volume per plot was reduced from $3.785 \mathrm{~L}$ in field trials 1 through 3 to $325 \mathrm{~mL}$ to more accurately represent volumes used in commercial production. Applications were conducted 6, 7, and 8 WAS, and plants were evaluated 9 WAS. Treatments and supporting information are summarized in Table 1.

\section{Plant evaluations}

Plant collection. For the greenhouse experiments, the six plants in each pot were cut at the stem below the base of the rosette leaves and immediately analyzed for bolting and biometric parameters. For the field trials, a sampling quadrat was used to randomly collect 10 (field trial 1) and 20 (field trial 2) plants from a sample subplot $(2.44 \mathrm{~m} \times$ $0.76 \mathrm{~m}, 1.85 \mathrm{~m}^{2}$ ) in the center of each treatment plot. Plants were cut at the stem below the base of the rosette leaves, pooled by plot, bagged in macroperforated clear polyethylene bags, and transported to the laboratory for assessment of bolting and other biometric parameters.

Biometric measurements. Plants were defined as bolting when internodes measured at least $1 \mathrm{~cm}$ in length. Plant length was determined from the base of the first rosette leaf to the length of the distal end of the leaves when laid on end, excluding any aberrant leaves. The stem diameter was measured with a digital caliper directly beneath the first true leaf of each plant. If a plant was scored as bolting, then the longest internode on the caulis (in rosette plants, the main stem that elongates before anthesis) or the total length of the caulis (field trial 4) was measured. Finally, the fresh weight of each plant was determined (not measured for field trial 4).

Leaf morphology changes. In the field trials, the percentage of plants displaying leaf morphology changes (inflorescent stems with leaves of highly pinnate to filiform morphology) was assessed in whole plots before harvest. In field trials 2 and 3 , the percentage of plants with leaf morphology changes was additionally assessed 1 and 2 weeks after harvest (WAH) in regrown plants; we were unable to collect these data for field trials 1 and 4 because fields were accidentally plowed shortly after harvest.

Yield. The yield for field trial 1 was determined as the total biomass of 20 random plants from the sample subplot. The yield for field trials 2 through 4 was determined as the total biomass of all plants in the sample subplot and expressed as $\mathrm{kg} / \mathrm{m}^{2}$ standardized to the average plant density per plot. Yields were determined on location immediately after harvest using a commercial scale (CWP-150, CAS-USA, East Rutherford, NJ).

\section{Statistical analysis}

Measurements were averaged for the six plants grown in one pot (greenhouse experiments) or collected from each plot (field trials) before calculating treatment means, and $95 \%$ confidence intervals for each variable mean were constructed. Data were analyzed separately for each greenhouse experiment and each field trial. Analysis of variance (ANOVA) was conducted using $R$ in the RStudio environment ( $\mathrm{R}$ Core Team, 2018; RStudio Team, 2016). The means from significant tests were separated with Tukey's honestly significant difference (HSD) test using the "Agricolae" package (de Mendiburu, 2017). One-way ANOVA was employed for greenhouse experiments. RCBD ANOVA was employed for field trials with treatment as a main factor and block as a random factor (trials 1-3) or treatment and application time as the main factors and block as a random factor (trial 4). Means were separated by Tukey's HSD test. Differences were defined as statistically significant when the $P$ value was $<0.05$. Graphs were constructed using the "ggplot2" package (Wickham, 2016).

\section{Results}

\section{Greenhouse experiments}

In both greenhouse experiments, GA treatment significantly increased plant length and induced bolting in $100 \%$ of the plants (Table 2) with many plants displaying leaves with pinnate to filiform morphology typical of cilantro plants that have initiated flowering (Fig. 1). In Expt. 1, plants treated with both PBZ and CQC were significantly shorter $(30.5 \mathrm{~cm}$ and $31.8 \mathrm{~cm})$ and bolted less frequently $(11.7 \%$ and $24.2 \%)$ than the UTC plants, which were $39.3 \mathrm{~cm}$ long and bolted with a frequency of $82.8 \%$. In Expt. 2, only PBZ significantly reduced bolting (30.6\%) compared with the UTC $(71.1 \%)$. Plant fresh weight was not significantly affected by any of the treatments in Expt. 1 . In Expt. 2, plants treated with MFL were significantly reduced in weight and in length compared with the UTC and displayed severe apical growth aberrations. No growth aberrations were observed for the other treatments. The internodes of plants from Expt. 2 were shortest in MFL treated plants (2.0 $\mathrm{cm})$ and longest in GA-treated plants $(8.8$ $\mathrm{cm})$, but no significant differences were found among plants having received PCa1 or PBZ compared with the UTC.

\section{Field trials}

Bolting. In field trial 1, plants treated with PCa1 bolted at a significantly lower percentage $(25.0 \%)$ compared with PBZ-treated plants and the UTC, which bolted at a percentage of $67.5 \%$ and $97.5 \%$, respectively (Table 3). Plot-to-plot variability for percent bolting of PBZ-treated plants was high, 
Table 2. Plant length, percent bolting, fresh weight, and internode length of cilantro (cv. Santo) plants from greenhouse Expts. 1 and 2 after treatment with different plant growth regulators.

\begin{tabular}{|c|c|c|c|c|c|c|c|c|}
\hline \multirow[b]{2}{*}{ Treatment } & \multicolumn{2}{|c|}{ Plant length $(\mathrm{cm})$} & \multicolumn{2}{|c|}{ Bolting (\%) } & \multicolumn{2}{|c|}{ Fresh wt (g) } & \multicolumn{2}{|c|}{ Internode length $(\mathrm{cm})$} \\
\hline & Expt. 1 & Expt. 2 & Expt. 1 & Expt. 2 & Expt. 1 & Expt. 2 & Expt. 1 & Expt. 2 \\
\hline GA & $57.3 \pm 4.0 \mathrm{a}$ & $36.9 \pm 10.2 \mathrm{a}$ & $100.0 \pm 0.0 \mathrm{a}$ & $100.0 \pm 0.0 \mathrm{a}$ & $34.8 \pm 9.4$ & $18.1 \pm 8.3 \mathrm{ab}$ & - & $8.8 \pm 1.7 \mathrm{a}$ \\
\hline PBZ & $30.5 \pm 1.8 \mathrm{c}$ & $21.0 \pm 5.1 \mathrm{bc}$ & $11.7 \pm 14.6 \mathrm{~b}$ & $30.6 \pm 23.2 \mathrm{~b}$ & $25.6 \pm 6.4$ & $19.3 \pm 4.5 \mathrm{ab}$ & - & $6.1 \pm 2.7 \mathrm{ab}$ \\
\hline $\mathrm{CQC}$ & $31.8 \pm 4.1 \mathrm{c}$ & - & $24.2 \pm 22.4 \mathrm{~b}$ & - & $24.3 \pm 12.5$ & - & - & - \\
\hline MFL & - & $15.4 \pm 2.4 \mathrm{c}$ & - & $71.1 \pm 25.8 \mathrm{a}$ & - & $12.9 \pm 5.5 \mathrm{~b}$ & - & $2.0 \pm 1.0 \mathrm{c}$ \\
\hline Avg & $39.7 \pm 4.8$ & $24.3 \pm 3.4$ & $54.7 \pm 17.2$ & $67.9 \pm 11.0$ & $28.9 \pm 3.9$ & $17.6 \pm 2.4$ & - & $5.1 \pm 1.1$ \\
\hline
\end{tabular}

Values presented are the mean \pm the $95 \%$ confidence interval $(\mathrm{n}=4)$. Different letters within columns indicate significant differences according to Tukey's honestly significant difference test. Internode length was not measured in Expt. 1 . UTC $=$ untreated control; GA $=$ gibberellic acid; PBZ $=$ paclobutrazol; PCa1 $=$ prohexadione calcium; $\mathrm{CQC}=$ chlormequat chloride; $\mathrm{MFL}=$ mefluidide.

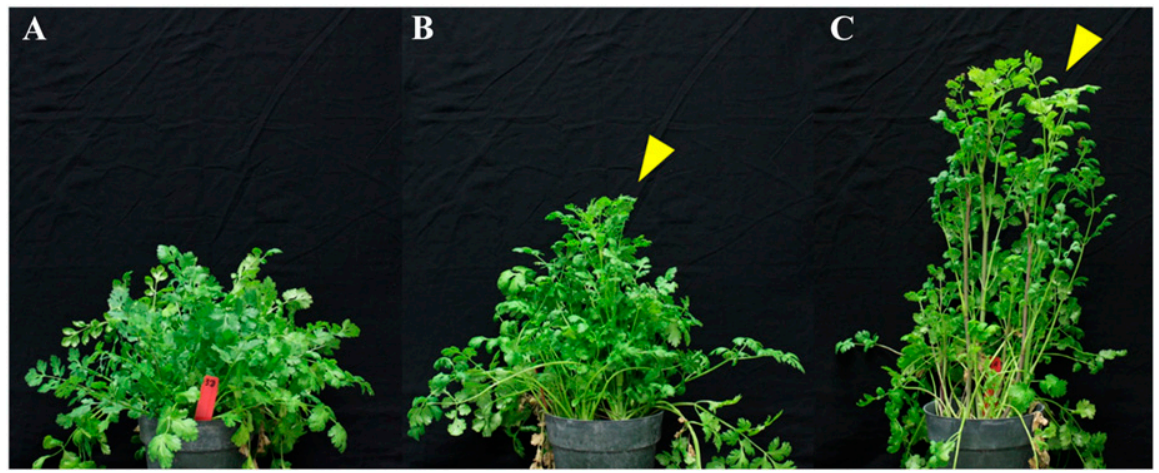

Fig. 1. Cilantro (cv. Santo) plants from greenhouse Expt. 1 treated with (A) paclobutrazol (PBZ), (B) no growth regulator [untreated control (UTC)], and (C) gibberellic acid (GA). Photos were taken 10 weeks after harvest. The yellow arrows point to leaves with pinnate to filiform morphology typical of cilantro plants that have initiated flowering. Note the more compact growth habit in the PBZ-treated plants and the elongated stems in GA-treated plant compared with the UTC.

ranging from $30 \%$ to $90 \%$. In trial 2 , plants treated with both PCa1 and PBZ bolted significantly less frequently $(8.8 \%$ and $13.8 \%)$ than MFL-treated plants and the UTC $(41.3 \%$ and $40.0 \%)$. In trial 3 , the percentage of bolting ranged from $1.3 \%$ to $11.3 \%$, and no significant differences were measured among differently treated plants.

In trial 4, a significant effect was found for both treatment and application time, but the interaction between the two factors was not significant (Fig. 2A). The average percentage of bolting in the UTC plots was $95 \%$. Both $\mathrm{PCa} 1$ and $\mathrm{PCa} 2$ reduced the incidence of bolting to $72.5 \%$ and $73.5 \%$, respectively. Plants bolted less frequently when they were sprayed at 6 and 7 WAS than when they were sprayed at 8 WAS. Block was significant at a level of $0.4 \%$, but no interaction with main effects was observed.

Leaf morphology changes. The percentage of plants with leaf morphology changes was significantly different among treatments in three of the four field trials (Table 3, Fig. 2B). In field trial 1, leaf morphology changes occurred least frequently in PCa1 treated plants $(1.7 \%)$, followed by PBZ treated plants $(17.9 \%)$, and most frequently in the UTC $(39.6 \%)$. In field trial 2, the average percentage of plants with leaf morphology changes was low $(1.1 \%)$, with the lowest percentage observed for PCa1- and PBZ-treated plants $(0.4 \%)$ and the highest percentage observed for plants treated with MFL (2.9\%). In trial 3, none of the plants displayed leaf morphology changes at the time of harvest. In field trial 4, both treatment and application time were significant factors and significantly interacted; leaf morphology changes occurred least frequently in plants treated with $\mathrm{PCa} 1$ and $\mathrm{PCa} 2$ at 6 and 7 WAS (7.3\% to $11.4 \%$ ) and most frequently in untreated plants (33.3\% to $36.5 \%$ ), regardless of the application time (Fig. 2B). Block was not a significant factor.

Leaf morphology changes after harvest. The percentage of plants with changed leaf morphology was assessed 1 and $2 \mathrm{WAH}$ in field trials 2 and 3 . Significant differences were found in field trial 2 at 1 WAH (Table 3 ) with the highest percentage measured for the UTC $(32.6 \%)$ and the lowest percentage measured for PCa1-treated plants $(14.5 \%)$. The average percentage of plants with changed leaf morphology at 2 WAH in field trial 2 was $45.4 .5 \%$ with no significant difference among treatments. In field trial 3, the average percentage of plants with changed leaf morphology after harvest was $28.6 \%$ (1 WAH) and 61.9\% (2 WAH) but did not differ significantly among treatments.

Plant biometrics. Application of growth regulators did not significantly influence plant length in trials 1 and 3 , which averaged $44.3 \mathrm{~cm}$ and $46.1 \mathrm{~cm}$, respectively (Table 4). Plant length in trial 2 varied significantly among treatments. Plants treated with MFL were shortest $(39.5 \mathrm{~cm})$, while the UTC plants were longest $(46.9 \mathrm{~cm})$. Neither PCa1- nor PBZ-treated plants were different in length from the UTC plants. Block was a significant factor for plant length in field trial 2.

In trial 4 , both treatment and application time significantly affected plant length, but there was no significant interaction (Fig. 2C). PCa1- and PCa2-treated plants were significantly shorter $(53.6 \mathrm{~cm}$ and $54.7 \mathrm{~cm})$ compared with the UTC $(58.2 \mathrm{~cm})$. Application of treatments at 6 and 7 WAS resulted in shorter plants $(54.6 \mathrm{~cm}$ and $54.8 \mathrm{~cm})$ than applications at 8 WAS $(57.1 \mathrm{~cm})$. Block was a significant factor $(P<0.0001)$, as was the interaction of block with treatment $(P=$ $0.0463)$ and application time $(P=0.0313)$.

The average stem diameters of plants ranged from $8.4 \mathrm{~mm}$ in field trial 4 to $9.8 \mathrm{~mm}$ in field trial 1 and no significant differences were found among treatments in any of the trials (data not shown).

The length of the longest internode of bolting plants was measured in field trials 1 through 3 (Table 4). Internode length was a significant trait in trial 1; plants treated with PCal had the shortest internodes $(3.2 \mathrm{~cm})$, and UTC plants had the longest $(6.7 \mathrm{~cm})$. No significant differences for internode length were measured in trials 2 and 3. Block was not a significant factor in any of the three trials.

Caulis length was measured for bolting plants in trial 4 (Fig. 2D). Treatment was a significant factor; caules of plants treated with PCa1 and PCa 2 were significantly shorter $(28.6$ and $29.7 \mathrm{~cm})$ than caules of untreated plants $(41.1 \mathrm{~cm})$. Caulis length was not significantly affected by application time, and no interaction between main effects was observed. Block was a significant factor $(P<$ $0.0001)$ and interacted significantly with application time $(P=0.0011)$. A significant interaction was also found for block, application time, and treatment $(P=0.0045)$. There was a moderate positive correlation ( $R=0.5214, P<0.0001)$ between caulis length and the incidence of bolting across all treatments.

The average fresh weight of plants from trials 1 through 3 ranged from $50.0 \mathrm{~g}$ in trial 1 to $89.0 \mathrm{~g}$ in trial 2 (Table 5). Significant 


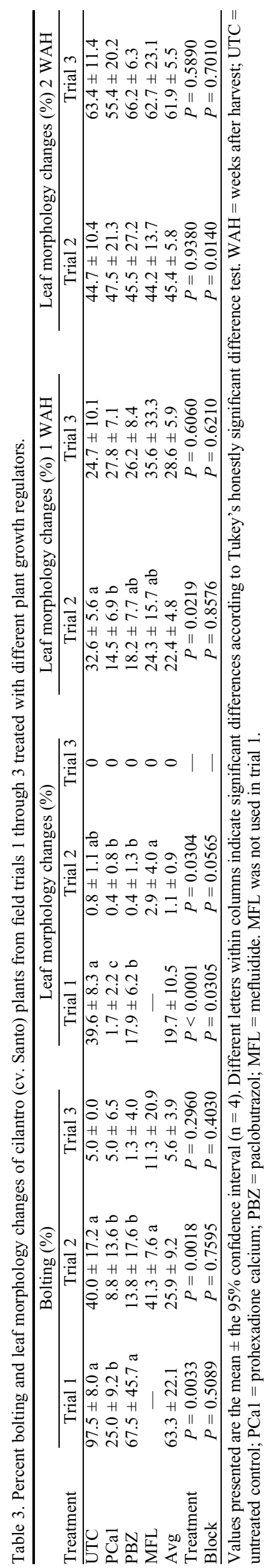

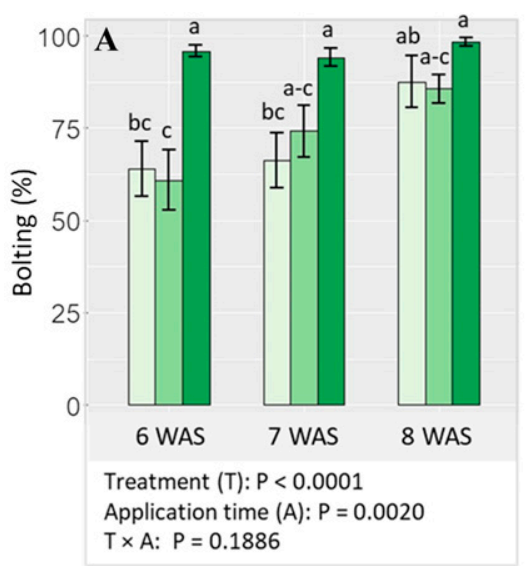

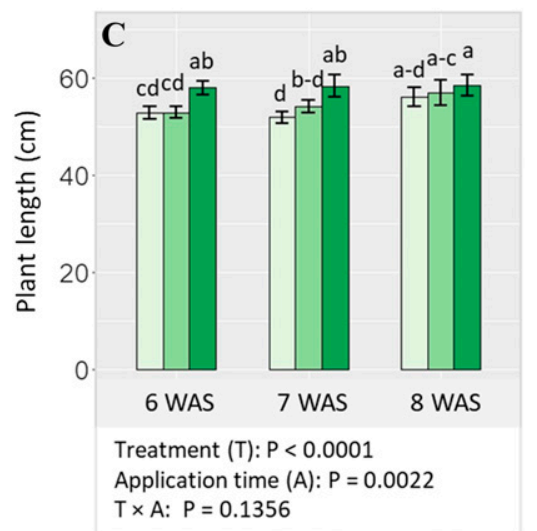

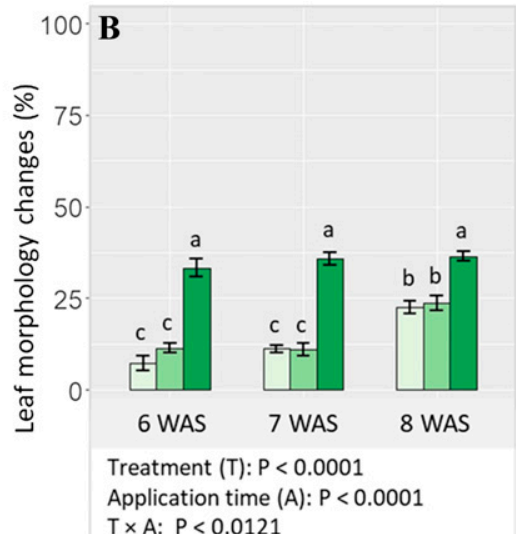

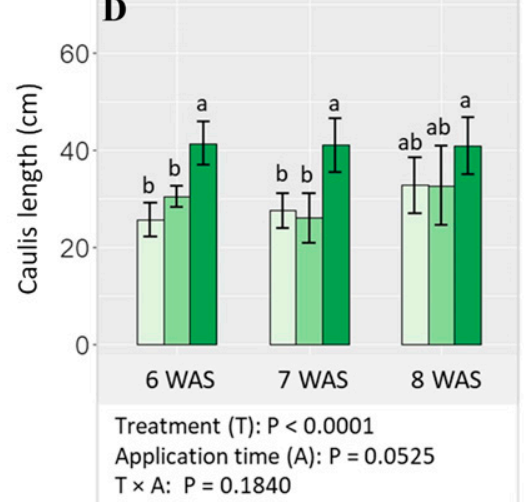

Fig. 2. Percent bolting (A), percent leaf morphology changes (B), plant length (C), and caulis length (D) of cilantro (cv. Santo) plants from field trial 4 after application of prohexadione calcium (PCa1 and PCa2) at 6, 7, and 8 weeks after seeding (WAS). Plants were assessed at 9 WAS. Values presented are the mean \pm the SE $(n=6)$. Different letters above bars indicate significant differences according to Tukey's honestly significant difference test. UTC $=$ untreated control.

differences among plants from the different treatments were only found in trial 2 where MFL-treated plants weighed significantly less (79.4 g) than UTC plants (101.7 g). Fresh weight per plant was not measured in trial 4 .

The yield for trial 1, expressed as the combined weight of 20 plants per plot, was $1.0 \mathrm{~kg}$ on average but did not differ significantly among treatments (Table 5 ). The yield for trials 2 and 3, expressed as plant weight per square meter, was $4.3 \mathrm{~kg} / \mathrm{m}^{2}$ in trial 2 and $5.1 \mathrm{~kg} / \mathrm{m}^{2}$ in trial 3 , but no significant differences were found among plants from the different treatments. Block was a significant factor in field trial 2.

The yield for field trial 4 ranged from 4.5 $\mathrm{kg} / \mathrm{m}^{2}$ when plants were treated with PCa1 to $4.9 \mathrm{~kg} / \mathrm{m}^{2}$ when plants were untreated, but differences were not significant (data not shown). Yields of plants treated at 6,7 , or 8 WAS ranged from 4.7 to $4.8 \mathrm{~kg} / \mathrm{m}^{2}$ with no significant differences among application times. No interaction of yield and application time was found. Block was not a significant factor.

\section{Discussion}

Preharvest bolting in rosette plants entails rapid stem elongation and floral initiation and is an undesirable trait in many leafy crops such as lettuce, cabbage, and spinach. In field-grown cilantro, it can cause significant reductions in leaf yield and therefore profitability. High temperatures and increased daylength are factors thought to exacerbate bolting (Morales-Payan, 2011); however, it is not practical to control these in large openfield production systems. GA is known to have repressive effects on flowering and bud formation in perennial, woody plants, but promotes bolting in most herbaceous plant species ( $\mathrm{Li}$ et al., 2018; Vanstraelen and Benková, 2012). Previous research that focused on increasing leaf yield in cilantro (cv. Santo) reported increased incidences of bolting in response to exogenous applications of GA (Kahn and Maness, 2010). GA was also found to be effective in decreasing the time to flowering in other cilantro cultivars (Kurmi et al.,2019; Yugandhar et al., 2014). Our pilot experiments conducted in the greenhouse and using the cilantro cultivar 'Santo' confirmed these findings. These pilot experiments also demonstrated that plant growth regulators that inhibit GA biosynthesis such as PBZ could effectively reduce bolting. GA biosynthesis inhibitors were previously examined regarding their influence on growth and anatomical characteristics of greenhousegrown cilantro (Kofidis et al., 2008). To assess whether these PGRs are also effective 
Table 4. Plant length and internode length of cilantro (cv. Santo) plants from field trials 1 through 3 treated with different plant growth regulators.

\begin{tabular}{|c|c|c|c|c|c|c|}
\hline \multirow[b]{2}{*}{ Treatment } & \multicolumn{3}{|c|}{ Plant length $(\mathrm{cm})$} & \multicolumn{3}{|c|}{ Internode length $(\mathrm{cm})$} \\
\hline & Trial 1 & Trial 2 & Trial 3 & Trial 1 & Trial 2 & Trial 3 \\
\hline UTC & $44.4 \pm 7.7$ & $46.9 \pm 6.1 \mathrm{a}$ & $47.5 \pm 11.6$ & $6.7 \pm 2.6 \mathrm{a}$ & $3.1 \pm 0.9$ & $2.8 \pm 3.0$ \\
\hline PCa1 & $46.0 \pm 3.9$ & $44.2 \pm 8.8 \mathrm{a}$ & $47.8 \pm 5.5$ & $3.2 \pm 2.3 \mathrm{~b}$ & $2.6 \pm 2.5$ & $1.7 \pm 1.8$ \\
\hline PBZ & $42.5 \pm 4.9$ & $45.3 \pm 5.3 \mathrm{a}$ & $45.7 \pm 4.4$ & $5.6 \pm 2.8 \mathrm{ab}$ & $2.8 \pm 0.8$ & $2.0 \pm 0.0$ \\
\hline MFL & - & $39.5 \pm 6.9 b$ & $43.5 \pm 9.1$ & - & $3.2 \pm 0.7$ & $2.4 \pm 1.4$ \\
\hline Avg & $44.3 \pm 2.3$ & $44.0 \pm 2.6$ & $46.1 \pm 2.6$ & $5.1 \pm 1.4$ & $3.0 \pm 0.4$ & $2.3 \pm 0.8$ \\
\hline Treatment & $P=0.5060$ & $P=0.0042$ & $P=0.6900$ & $P=0.0235$ & $P=0.7620$ & $P=0.6540$ \\
\hline Block & $P=0.7600$ & $P=0.0009$ & $P=0.7780$ & $P=0.1557$ & $P=0.3050$ & $P=0.1750$ \\
\hline
\end{tabular}

Values presented are the mean \pm the $95 \%$ confidence interval $(n=4)$. Different letters within columns indicate significant differences according to Tukey's honestly significant difference test. UTC $=$ untreated control; PCa1 = prohexadione calcium; PBZ = paclobutrazol; $\mathrm{MFL}=$ mefluidide. $\mathrm{MFL}$ was not $\mathrm{used}$ in trial 1 .

Table 5. Fresh weight and yield of cilantro (cv. Santo) plants from field trials 1 through 3 treated with different plant growth regulators.

\begin{tabular}{|c|c|c|c|c|c|c|}
\hline \multirow[b]{2}{*}{ Treatment } & \multicolumn{3}{|c|}{ Fresh wt (g/plant) } & \multirow{2}{*}{$\frac{\text { Yield }(\mathrm{kg} / 20 \text { plants })}{\text { Trial } 1}$} & \multicolumn{2}{|c|}{ Yield $\left(\mathrm{kg} / \mathrm{m}^{2}\right)$} \\
\hline & Trial 1 & Trial 2 & Trial 3 & & Trial 2 & Trial 3 \\
\hline$\overline{\mathrm{UTC}}$ & $49.0 \pm 21.1$ & $101.7 \pm 17.9 \mathrm{a}$ & $59.9 \pm 14.5$ & $1.05 \pm 0.4$ & $4.1 \pm 1.0$ & $5.0 \pm 2.4$ \\
\hline PCa1 & $46.8 \pm 10.9$ & $85.8 \pm 10.1 \mathrm{ab}$ & $65.5 \pm 22.6$ & $0.93 \pm 0.2$ & $4.6 \pm 1.1$ & $6.1 \pm 2.3$ \\
\hline PBZ & $54.1 \pm 21.1$ & $89.1 \pm 21.1 \mathrm{ab}$ & $64.9 \pm 13.9$ & $1.08 \pm 0.1$ & $4.6 \pm 0.5$ & $4.6 \pm 2.7$ \\
\hline MFL & - & $79.4 \pm 7.1 \mathrm{~b}$ & $60.3 \pm 20.4$ & - & $4.0 \pm 0.4$ & $5.3 \pm 3.6$ \\
\hline Avg & $50.0 \pm 6.9$ & $89.0 \pm 6.4$ & $62.6 \pm 5.6$ & $1.0 \pm 0.1$ & $4.3 \pm 0.5$ & $5.1 \pm 0.8$ \\
\hline Treatment & $P=0.6380$ & $P=0.0477$ & $P=0.8630$ & $P=0.3300$ & $P=0.3023$ & $P=0.3390$ \\
\hline Block & $P=0.3300$ & $P=0.4054$ & $P=0.6000$ & $P=0.2230$ & $P=0.0085$ & $P=0.2470$ \\
\hline
\end{tabular}

Values presented are the mean \pm the $95 \%$ confidence interval $(n=4)$. UTC $=$ untreated control; PCa1 $=$ prohexadione calcium; $\mathrm{PBZ}=$ paclobutrazol; $\mathrm{MFL}=$ mefluidide. MFL was not used in trial 1.

in a commercial open-field environment, we conducted four field trials between Nov. 2016 and April 2018. GA biosynthesis inhibitors have been successfully used to curtail bolting in Chinese cabbage, spinach, and lettuce (Abed, 2018; Fukuda et al., 2005; Pressman and Aviram, 1986). In cilantro, applications of indole-3-acetic acid and kinetin delayed the onset of flowering (Hernández-Dávila et al., 2004), but GA biosynthesis inhibitors were not examined in that study.

Although PBZ was effective in reducing the frequency of bolting in the greenhouse experiments, it was less effective in the field trials. In field trial 2 , bolting was reduced by $65 \%$ compared with the UTC, but in trial 1 , any effects that may have been present were masked by high variation among PBZ-treated plots. The differences between greenhouse and field results may have been caused by the stronger retention of PBZ in the peat-based potting medium compared with the sandy permeable soils present at the farm site (Environmental Protection Agency, 2007). In addition, a larger volume per plant was used in the greenhouse experiments than in the field trials. In contrast to PBZ, PCa was highly effective in field trials and reduced bolting by $74 \%$ to $78 \%$ in trials 1 and 2 and by $21 \%$ to $36 \%$ in trial 4 . The lower efficacy of $\mathrm{PCa}$ in field trial 4 could have been a consequence of the reduced spray volume used in that trial. Although the reduced spray volume more accurately reflects spray volumes used by growers, it may not have provided enough coverage.

The average percentage of bolting in field trial 3 was low with no differences among treatments, despite the longer average daylength during this trial compared with trials 1 and 2. Fluctuations in temperature, as discussed later in this section, may have contributed to these findings.
MFL, a plant growth regulator used to inhibit vegetative growth and seed head formation in turfgrass, reduced plant length and caused apical growth aberrations but had no effect on bolting in greenhouse experiments or field trials. MFL is a fast-acting PGR that rapidly accumulates in the apical meristem where it inhibits mitosis within $48 \mathrm{~h}$ of application (March et al., 2013; Tautvydas, 1983); however, time of application and concentration must be precisely optimized to be effective (Christians, 2001). Therefore, this compound may be more effective in suppressing bolting in cilantro when applied at lower concentrations and several days before bolting instead of several weeks as explored in our study.

CQC, which, like PBZ and $\mathrm{PCa}$, inhibits GA biosynthesis and reduced bolting incidence by $70 \%$ in greenhouse Expt. 1, was not used in the open-field trials because of the potential environmental hazards listed on the label. In addition to effectively reduce bolting, greenhouse-grown plants treated with CQC were shorter compared with untreated plants, which is similar to results obtained in field-grown lettuce (Passam et al., 2008). PBZ reduced plant length in greenhouse Expt. 1 but had no effect on plant length in the field trials. PCa reduced plant length only in field trial 4 but reduced neither plant length nor percentage of bolting in greenhouse Expt. 2. A strong effect of $\mathrm{PCa}$ on plant length was observed in a study by Kofidis et al. (2008); however, $\mathrm{PCa}$ concentrations were higher, and plants were sprayed multiple times and were measured after fruit ripening.

Applications of PGRs were performed at different time points (weeks) after seeding. The greatest reductions in the incidence of bolting under open-field conditions were observed when plants received applications at 5 to $6 \mathrm{WAS}$ and were harvested at $8 \mathrm{WAS}$, although applications of PCa at 7 WAS were also effective when plants were harvested 2 weeks later (9 WAS). When plants received $\mathrm{PCa}$ at $8 \mathrm{WAS}$ and were harvested at $9 \mathrm{WAS}$, effects were diminished. This suggests that for the effects of GA biosynthesis inhibiting growth regulators to become manifest in cilantro, applications should commence at a minimum of 2 weeks before the anticipated time of bolting. This period may not be appropriate for PGRs with a different mode of action, such as MFL.

Field trials 2 and 3 were sown in adjacent fields and 1 week apart from each other. The percentage of bolting in the untreated plots was $40 \%$ in trial 2 compared with $5 \%$ in trial 3 . Detailed review of the climatic data during the time of the trials revealed a drop in the minimum temperature to $4{ }^{\circ} \mathrm{C}$ for a period of $12 \mathrm{~h}$, which occurred $10 \mathrm{~d}$ after seeding trial 3. It is possible that the sudden drop in temperature occurred at a developmental stage that is critical for floral induction, and that floral induction already occurred in plants of trial 2 where minimum temperatures were higher $\left(10-15^{\circ} \mathrm{C}\right)$ during the same time frame after seeding. PCa is absorbed quickly by plants and does not persist in the plant tissue, and thus applications made before induction of floral pathways may not effectively curtail bolting (Evans et al., 1999).

Because of the apparent strong influence of environmental conditions on cilantro development, a morphology marker indicative of the developmental stage may be more useful for determining the most effective time of application rather than the time after seeding and the estimated time of harvest. Stem diameter at the base of the rosette leaves was measured as one possible indicator of bolting in our field studies. However, in none of the trials did we observe any significant differences of stem diameter that was associated with bolting. 
Cilantro plants were further assessed to determine whether PGRs influence the internode length of the stem (caulis) during the later stage of bolting. Except for field trial 1, no internode length reductions were observed. In contrast, internode length was reduced in greenhouse-grown cilantro treated with PCa (Kofidis et al., 2008) and in fieldgrown tef treated with PBZ (Tesfahun, 2017). Different application rates and different environmental conditions are possible reasons for these variations.

In field trial 4, instead of internode length, the total length of the caules was assessed. Plants treated with $\mathrm{PCa}$ had significantly shorter caules than untreated plants. The average caulis length per plot was also moderately correlated with the percentage of bolting in each plot, suggesting that in addition to curtailing bolting, PCa also delayed caulis development in plants that had initiated bolting. Caulis length may therefore be a useful indicator of the developmental stage of cilantro in relation to flowering.

The biometric assessment of individual plants to determine the developmental stage is time consuming. To determine the percentage of bolting in open-field-grown cilantro more quickly, we measured the percentage of plants with leaf morphology changes typical for cilantro plants at a later stage of bolting. Although there were significant differences among PGRs that mirrored the results of bolting and caulis length, the visual assessments underestimated the percentage of bolting considerably in all field trials. However, this method was useful when assessing plants regrown after harvest because leaf morphology changes occurred immediately. In trial 2 , $\mathrm{PCa}$ reduced the percentage of plants with leaf morphology changes by more than $50 \%$ at $1 \mathrm{WAH}$ but was ineffective $2 \mathrm{WAH}$. This suggests that if a second harvest is desired, a second application before the first harvest may be necessary to prevent postharvest bolting beyond the first week of regrowth.

Neither the fresh weight of individual cilantro plants nor the yield per area was affected by PGR applications in both greenhouse and field trials. These results are different from results for okra and potatoes, where applications of PCa and PBZ reduced plant height and aboveground biomass (Ilias et al., 2007; Njiti et al., 2013). Reductions in yield resulting from PBZ applications have also been linked to reduced internode length in tef forage grass (Tesfahun, 2017). However, in contrast to these plants, cilantro is a rosette plant without a visible stem during the vegetative growth phase, precluding a direct comparison with nonrosette plants. In carrots, PBZ also decreased the shoot weight, but increased the weight and diameter of the roots (Wang et al., 2015). In that study, multiple PBZ applications were performed contrary to our study in which single applications were performed. Although we included both bolting and nonbolting plants to assess the yield in our study, in commercial cilantro production, plants displaying clear signs of bolting are usually not harvested.
Any reduction in bolting due to the activity of PGRs would therefore offset losses in marketable yield.

Although PBZ has found widespread use in mango cultivation to mitigate the effects of alternate bearing, research indicates that the compound can persist in field soils up to 6 months and negatively affect soil microbial and fungal diversity (Rademacher, 2016; Silva et al., 2003). PBZ residues in the soil also inhibited growth and development in potatoes and taro (Jiang et al., 2019) and reduced seed germination and plant growth in cucumber and tomato (Magnitskiy et al., 2006; Still and Pill, 2003). When used in closed capture irrigation systems, PBZ residues can accumulate and reduce growth of subsequent crops, which necessitates remediation (Grant et al., 2018). Therefore, routine use of PBZ may not be an option for growers cultivating in-field sown crops or rotating PBZ-sensitive crops. In our study, PBZ was not effective in reducing bolting in plants regrown after harvest, suggesting that it may not persist in the sandy soils typical for Florida's agricultural production systems. Conversely, PCa is fast acting, effective, and has low persistence in the environment. It is also one of the few GA inhibitors currently on the market that is labeled for use on some agricultural crops in the United States.

\section{Conclusion}

Our study suggests that GA is at least partially responsible for bolting in cilantro and, when applied exogenously, induces bolting under greenhouse conditions. PGRs that inhibit GA biosynthesis curtailed the incidence of bolting effectively when applied at 5 to 6 WAS both in the greenhouse and in a commercial open-field environment when plants were harvested 2 to 3 weeks later. $\mathrm{PCa}$ and PBZ were the most effective of the PGRs tested and reduced the incidence of bolting by up to $78 \%$. However, they had little to no residual effect on the bolting incidence of plants regrown for a second harvest. Applications of PCa and PBZ caused no reductions in plant fresh weights and yield compared with untreated plots. The results from our study suggest that use of $\mathrm{PCa}$ or PBZ may be an effective strategy to delay bolting in rosette plants like cilantro and reduce crop losses during growth conditions conducive to preharvest bolting.

\section{Literature Cited}

Abed, M. 2018. Effect of paclobutrazol on growth and delaying bolting of lettuce (Lactuca sativa L.) cv. Balady. Asian J. Agr. Hort. Res. 1:1-9.

Angeli, K.P., F.T. Delazari, C. Nick, M.G. Ferreria, and D.J.H. da Silva. 2016. Yield components and water use efficiency in coriander under irrigation and nitrogen fertilization. R. Bras. Eng. Agríc. Ambiental 20:415-420.

Bashtanova, U. and T.J. Flowers. 2011. Diversity and physiological plasticity of vegetable genotypes of coriander improves herb yield, habit and harvesting window in any season. Euphytica 180:369-384.

Beam, J.B., D. Jordan, A. York, T. Isleib, J.E. Bailey, T.E. McKemie, J.F. Spears, and P.D.
Johnson. 2002. Influence of prohexadione calcium on pod yield and pod loss of peanut. Agron. J. 94:331-336.

Bishopp, A., A.P. Mahonen, and Y. Helariutta. 2006. Signs of change: Hormone receptors that regulate plant development. Development 133:1857-1869.

Blade, S., M. Bandara, and S. Hu. 2016. AgriFacts: Coriander (Agdex 147/20-2). 18 Nov. 2019. <https://www1.agric.gov.ab.ca/\$department/deptdocs.nsf/all/agdex121/\$file/147_20-2. pdf?OpenElement>

Christians, N. 2001. Creative uses for plant growth regulators. USGA Green Sec. Rec. 39:11-13.

Cline, J. 2017. Prohexadione-Ca and ethephon suppress shoot growth of sweet cherry [Prunus avium (L.) L.]. Can. J. Plant Sci. 97:601-609.

Das, D., A.K. Bhadra, and M. Moniruzzaman. 2018. Foliar spray of gibberellic acid influences morphology attributes and foliage yield of coriander (Coriandrum sativum L.). Res. Agr. Livest. Fish. 5:1-9.

de Mendiburu, F. 2017. Agricolae: Statistical Procedures for Agricultural Research. R package version 1.2-8. $<$ https://cran.r-project.org/package $=$ agricolae $>$.

Diederichsen, A. 1996. Promoting the conservation and use of underutilized and neglected crops: Coriander (Coriandrum sativum L.). Intern. Plant Genet. Res. Inst. (IPGRI), Rome.

Diederichsen, A. and K. Hammer. 2003. The infraspecific taxa of coriander (Coriandrum sativum L.). Genet. Resources Crop Evol. 50:33-63.

Dugan, F.M., S.L. Lupien, and J. Hu. 2017. Fungal plant pathogens associated with emerging crops in North America: A challenge for plant health professionals. Plant Health Prog. 18: 221-229.

Environmental Protection Agency. 2007. Paclobutrazol summary document registration review. Initial docket. Available in docket number EPA-HQ-OPP-2006-0109 at <http://www. regulations.gov>.

Evans, J., R. Evans, C. Regusci, and W. Rademacher. 1999. Mode of action, metabolism, and uptake of BAS $125 \mathrm{~W}$, prohexadione-calcium. HortScience 34:1200-1201.

Fukuda, N., M. Kondo, S. Nishimura, M. Koshioka, S. Tanakadate, A. Ito, and L.N. Mander. 2005. The role of phytohormones in flowering and bolting of Spinach (Spinacia oleracea L.) under mid-night lighting. Acta Hort. 711: 247-254.

Grant, G.A., P.R. Fisher, J.E. Barrett, and P.C. Wilson. 2018. Removal of paclobutrazol from irrigation water using granular-activated carbon. Irrig. Sci. 36:159-166.

Haguewood, J.B., E. Song, R.J. Smeda, J.Q. Moss, and X. Xiong. 2013. Suppression of annual bluegrass seedheads with mefluidide, ethephon, and ethephon plus trinexapac-ethyl on creeping bentgrass greens. Agron. J. 105:1832-1838.

Hälvä, S., L. Craker, J. Simon, and D. Charles. 1993. Growth and essential oil in dill, Anethum graveolens $\mathrm{L}$., in response to temperature and photoperiod. J. Herbs Spices Med. Plants 1:47-56.

Hamner, K.C. and A.W. Naylor. 1939. Photoperiodic responses of dill, a very sensitive long day plant. Bot. Gaz. 100:853-861.

Hassan, F. and S. Mahfouz. 2012. Effect of 1methylcyclopropene (1-MCP) on the postharvest senescence of coriander leaves during storage and its relation to antioxidant enzyme activity. Scientia Hort. 141:69-75.

Hernández-Dávila, J., F. Zavala-García, C.G.S. Valdés-Lozano, G. Salinas-García, E. Cárdenas-Cerda, F. Montes-Cavazos, and $\mathrm{H}$. Gámez-González. 2004. Retraso de la floración 
en cilantro (Coriandrum sativum L.) con sustancias reguladoras del crecimiento. Rev. Chapingo Ser. Hort. 10:51-56.

Ilias, I., G. Ouzounidou, A. Giannakoula, and P. Papadopoulou. 2007. Effects of gibberellic acid and prohexadione-calcium on growth, chlorophyll fluorescence and quality of okra plant. Biol. Plant. 51:575.

Jenni, S., I. Gamache, J.C. Côté, and K.A. Stewart. 2005. Early field detection of bolting in celery. HortTechnology 15:843-845.

Jiang, X., Y. Wang, H. Xie, R. Li, J. Wei, and Y. Liu. 2019. Environmental behavior of paclobutrazol in soil and its toxicity on potato and taro plants. Environ. Sci. Pollut. Res. Intl. 26: 27385-27395.

Johnson, K. and M. Lenhard. 2011. Genetic control of plant organ growth. New Phytol. 191:319333.

Kahn, B.A. and N.O. Maness. 2010. Row arrangements, seeding rates, and gibberellic acid treatments to improve yield of machine-harvested cilantro. HortScience 45:1049-1051.

Kofidis, G., A. Giannakoula, and I. Ilias. 2008. Growth, anatomy and chlorophyll fluorescence of coriander plants (Coriandrum staivum L.) treated with prohexadione-calcium and daminozide. Acta Biol. Cracov. Ser. Bot. 50(2):55-62.

Kurmi, A.K., I.S. Naruka, S.S. Kushwah, and G.S. Chouhan. 2019. Effect of PGRs on growth, yield and quality of coriander (Coriandrum sativum L.) cv. NRCSS-Acr-1. Intl. J. Curr. Microbiol. Appl. Sci. 8:2162-2167.

Laribi, B., K. Kouki, M. M'Hamdi, and T. Bettaieb. 2015. Coriander (Coriandrum sativum L.) and its bioactive constituents. Fitoterapia 103:9-26.

Li, J., B.-Z. Pan, L. Niu, M.-S. Chen, M. Tang, and Z.-F. Xu. 2018. Gibberellin inhibits floral initiation in the perennial woody plant Jatropha curcas. J. Plant Growth Regul. 37:999-1006.

Luo, Y., J.L. McEvoy, M.R. Wachtel, J.G. Kim, and Y. Huang. 2004. Package atmosphere affects postharvest biology and quality of fresh-cut cilantro leaves. HortScience 39:567570 .

Magnitskiy, S.V., C.C. Pasian, M.A. Bennett, and J.D. Metzger. 2006. Effects of soaking cucumber and tomato seeds in paclobutrazol solutions on fruit weight, fruit size, and paclobutrazol level in fruits. HortScience 41:1446-1448.

March, S., D. Martins, and J. McElroy. 2013. Growth inhibitors in turfgrass. Planta Daninha 31:733-747.

McGrath, M.J., J.M. Koczan, M.M. Kennelly, and G.W. Sundin. 2009. Evidence that prohexadionecalcium induces structural resistance to fire blight infection. Phytopathology 99:591-596.

Morales-Payan, J.P. 2011. Herbs and leaf crops: Cilantro, broadleaf cilantro and vegetable am- aranth, p. 1-28. In: W.H. Verheye (ed.). Soils, plant growth and crop production. Encyclopedia of Life Support Systems (EOLSS), Eolss Publishers, Paris, France.

Morales-Payan, J.P. and W.M. Stall. 2004. Effect of selected growth stimulators on the yield of cilantro. HortScience 39:859D-859.

Nawata, E., J. Itanai, and Y. Masanaga. 1995. The distribution and dissemination pathway of coriander in Asia. Acta Hort. 390:167-174.

Njiti, V.N., Q. Xia, L.S. Tyler, L.D. Stewart, A.T. Tenner, C. Zhang, D. Alipoe, F. Chukwuma, and M. Gao. 2013. Influence of prohexadione calcium on sweetpotato growth and storage root yield. HortScience 48:73-76.

Passam, H., A. Koutri, and I. Karapanos. 2008. The effect of chlormequat chloride (CCC) application at the bolting stage on the flowering and seed production of lettuce plants previously treated with water or gibberellic acid (GA3). Scientia Hort. 116:117-121.

Pernezny, K., R. Raid, and J. Jones. 1997. Bacterial leaf spot of cilantro in Florida. Plant Dis. 81:232.

Peterson, L., R. Clark, and R. Menary. 1993. Umbel initiation and stem elongation in fennel (Foeniculum vulgare) initiated by photoperiod. J. Essent. Oil Res. 5:37-43.

Pikaard, C.S. and O.M. Scheid. 2014. Epigenetic regulation in plants. Cold Spring Harb. Perspect. Biol. 6:a019315.

Potter, T.L. 1996. Essential oil composition of cilantro. J. Agr. Food Chem. 44:1824-1826.

Pressman, E. and H. Aviram. 1986. Inhibition of flowering in Chinese cabbage by applying heat and growth retardants to transplants. Plant Growth Regulat. 4:87-94.

Putievsky, E. 1983. Effects of daylength and temperature on growth and yield components of three seed spices. J. Hort. Sci. 58:271-275.

Rademacher, W. 2015. Plant growth regulators: Backgrounds and uses in plant production. J. Plant Growth Regul. 34:845-872.

Rademacher, W. 2016. Chemical regulators of gibberellin status and their application in plant production, p. 359-403. In: P. Hedden and S.G. Thomas (eds.). Ann. Plant Rev., Vol. 49, The gibberellins. John Wiley \& Sons, Chichester, UK.

Ramin, A. and J. Atherton. 1994. Manipulation of bolting and flowering in celery (Apium graveolens L. var. dulce). III. Effects of photoperiod and irradiance. J. Hort. Sci. 69:861-868.

Reeves, P.H. and G. Coupland. 2001. Analysis of flowering time control in Arabidopsis by comparison of double and triple mutants. Plant Physiol. 126:1085-1091.

R Core Team. 2018. R: A Language and Environment for Statistical Computing. Vienna, Austria.
RStudio Team. 2016. RStudio: Integrated Development Environment for R. Boston, MA.

Silva, C.M.M.S., R.F. Vieira, and G. Nicolella. 2003. Paclobutrazol effects on soil microorganisms. Appl. Soil Ecol. 22:79-86.

Simpson, G.G. and C. Dean. 2002. Arabidopsis, the Rosetta stone of flowering time? Science 296: 285-289.

Smith, R., J. Bi, M. Cahn, M. Cantwell, O. Daugovish, S. Koike, E. Natwick, and E. Taklee. 2011. Cilantro Production in California, p. 4. University of California: Agriculture and Natural Resources.

Soil Survey Staff, Natural Resources Conservation Service, U.S. Department of Agriculture, Official Soil Series Descriptions. 2014. 18 Nov. 2019. $<$ https://soilseries.sc.egov.usda.gov/OSD_Docs/ B/BASINGER.html >.

Still, J.R. and W.G. Pill. 2003. Germination, emergence, and seedling growth of tomato and impatiens in response to seed treatment with paclobutrazol. HortScience 38:12011204.

Tautvydas, K.J. 1983. Synergistic growth retardation of grasses with mefluidide/PGR combinations. Proc. Plant Growth Regulator Soc. Amer. 10:51-56.

Tesfahun, W. 2017. Effect of rates and time of paclobutrazol application on growth, lodging, and yield and yield components of tef [Eragrostis Tef (Zucc.) Trotter] in Adadistrict, East Shewa, Ethiopia. J. Biol. Agr. Healthcare 7.

Tomitaka, Y., A. Karimata, and A. Noguchi. 2001. Effect of daylength on the flower bud differentiation and development in coriander (Coriandrum sativum L.). J. Agr. Sci., Tokyo Univ. of Agr. 46:196-200.

Vanstraelen, M. and E. Benková. 2012. Hormonal interactions in the regulation of plant development. Annu. Rev. Cell Dev. Biol. 28:463-487.

Wang, G.L., F. Que, Z.S. Xu, F. Wang, and A.S. Xiong. 2015. Exogenous gibberellin altered morphology, anatomic and transcriptional regulatory networks of hormones in carrot root and shoot. BMC Plant Biol. 15:290.

Wickham, H. 2016. ggplot2: Elegant graphics for data analysis. Springer-Verlag New York, NY.

Yugandhar, V., P.S.S. Reddy, G. Thanuja Sivaram, and D.S. Reddy. 2014. Effect of growth regulators on growth, seed yield and quality of coriander (Coriandrum sativum L.) cv. Sudha. Plant Arch. 14:1083-1086.

Yugandhar, V., P.S.S. Reddy, G. Thanuja Sivaram, and D.S. Reddy. 2016. Influence of plant growth regulators on growth, seed yield, quality and economics of coriander (Coriandrum sativum L.) cv. Sudha. J. Spices Aromatic Crops 25:13-17. 